Отримано: 13 грудня 2020 p.

Прорецензовано: 02 січня 2021 р.

Прийнято до друку: 11 січня 2021 р.

e-mail: avmvpmailru@gmail.com

DOI: $10.25264 / 2311-5149-2021-20(48)-59-66$

Коноваленко А. С. Індикатори управління безпекою харчування дітей. Наукові записки Начіонального університету "Острозька академія». Серія "Економіка» : науковий журнал. Острог : Вид-во НаУОА, березень 2021. № 20(48). С. 59-66.

УДК: 338.439 .02

JEL-кодифікація: $M 31$

ORCID-ідентифікатор: 0000-0001-9061-5989

Коноваленко Анастасія Сергї̈вна,

кандидат економічних наук, доцент, доцент кафедри маркетингу

Таврійського державного агротехнологічного університету ім. Д. Моторного

\title{
ІНДИКАТОРИ УПРАВЛІННЯ БЕЗПЕКОЮ ХАРЧУВАННЯ ДІТЕЙ
}

Забезпечення безпеки харчування дітей є стратегічним завданням держави та потребує наукового обгрунтування шияхів, напрямів використання існуючого потенціалу його підвищення. У статті запропоновано алгоритм моніторингу ефективності управління, що передбачає послідовні етапи з урахуванням впровадження маркетингового механізму. Розробка стратегічних напрямів підвищення безпеки харчування дітей потребує моніторингу поточного стану, визначення чинників існуючої динаміки, ще ускладнено відсутністю методичних підходів до оцінки ефективності управління безпекою харчування.

На основі аналізу компонентів продовольчої безпеки зазначено параметри безпеки харчування дітей, засновані на критеріях Римської декларачії про всесвітню продовольчу безпеку та FАО. Запропоновано систему ключових індикаторів рівня безпеки харчування дітей, які передбачають макроекономічні та маркетингові індикатори, щуо характеризують рівень фізичної та фінансової доступності продовольства, якості та безпечності продуктів харчування, а також враховують поведінковий аспект. Окреслено методи збору інформації для оиінки управління безпекою харчування дітей, щуо передбачають отримання як вторинної, так і первинної інформації.

Ключові слова: безпека харчування, індикатори, споживач, продовольча безпека, поведінка спожсивача.

Коноваленко Анастасия Сергеевна,

кандидат экономических наук, дочент, доиент кафедры маркетинга

Таврического государственного агротехнологического университета им. Д. Моторного

\section{ИНДИКАТОРЫ УПРАВЛЕНИЯ БЕЗОПАСНОСТЬЮ ПИТАНИЯ ДЕТЕЙ}

Обеспечение безопасности питания детей является стратегической задачей государства и требует научного обоснования путей, направлений использования существующего потенциала его повышения. В статье предложен алгоритм мониторинга эффективности управления, который предполагает последовательные этапь с учетом внедрения маркетингового механизма. Разработка стратегических направлений повышения безопасности питания детей требует мониторинга текущего состояния, определения факторов существующей динамики, что затруднено отсутствием методических подходов к оиенке эффективности управления безопасностью питания детей.

На основе анализа компонентов продовольственной безопасности указано параметры безопасности питания детей, основанные на критериях Римской декларации о всемирной продовольственной безопасности и FАО. Предложена система ключевых индикаторов уровня безопасности питания детей, предусматривающих макроэкономические и маркетинговые индикаторы, характеризующие уровень физической и финансовой доступности продовольствия, качества и безопасности продуктов питания, а также учитывают поведенческий аспект. Определены методы сбора информации для оценки управления безопасностью питания детей, которые предполагают получение в качестве вторичной, так и первичной информации.

Ключевые слова: безопасность питания, индикаторы, потребитель, продовольственная безопасность, поведение потребителя.

\author{
Anastasiia Konovalenko, \\ PhD in Economics, Associate Professor, Department of Marketing, \\ Dmytro Motornyi Tavria State Agrotechnological University
}

\section{CHILD NUTRITION SAFETY MANAGEMENT INDICATORS}

Ensuring the safety of children's nutrition is a strategic task of the state and requires a scientific justification of ways, directions of using the existing potential to increase it. The article considers approaches to assessing the effectiveness of nutrition management of school-age children, proposes an algorithm for monitoring the effectiveness of management, which provides for the cyclical implementation of a number of successive stages, taking into account the implementation of the 
marketing mechanism. It is noted that according to the overall rating of the Global Food Security Index, Ukraine in 2019 improved its position compared to the previous period, which characterizes the presence of positive changes in the field of food security. However, the adjustment of existing programs and the development of new strategic directions for improving the safety of children's nutrition requires monitoring of the current situation, determining the factors of the existing dynamics, which is complicated by the lack of methodological approaches to assessing the effectiveness of food safety management.

Based on the analysis of the components of food security, the children' food safety parameters based on the criteria of the Rome Declaration on World Food Security and FAO are indicated. A system of key indicators for children's food safety is proposed, providing macroeconomic and marketing indicators that characterize the level of physical and financial availability of food, quality and safety of food, and take into account behavioral aspects (namely motivated choice of healthy food by children). The behavioral aspect of food safety is manifested through the model of children's consuming behavior in the market. Methods of collecting information for the assessment of child nutrition safety management, which provide for obtaining both secondary and primary information, are outlined.

Keywords: food safety, indicators, consumer, food security, consumer behavior.

Постановка проблеми. Забезпечення належного рівня харчування дітей є стратегічним завданням держави та потребує всебічного й комплексного наукового обгрунтування шляхів, напрямів використання існуючого потенціалу його підвищення. Однак, обгрунтування стратегії підвищення рівня безпеки харчування дітей ускладняється відсутністю методичної бази для здійснення поточного стану оцінки ефективності управління безпекою харчування дітей, відсутністю загальних методичних підходів до визначення безпекових аспектів харчування дітей шкільного віку, не існує обгрунтованої системи індикаторів та підходів до надання кількісної оцінки наслідкам управлінських рішень в сфері вирішення соціальних проблем суспільства. Вирішення цього завдання можливо здійснити на основі розробки системи індикаторів управління безпекою харчування дітей шляхом комбінування кількісних, якісних, соціометричних та інформативних методів оцінювання.

Аналіз останніх досліджень і публікацій. Значна кількість наукових напрацювань вітчизняних вчених присвячена моніторингу рівня та якості харчування дітей в Україні з огляду на його вплив на стан здоров'я дітей. У своїх роботах дослідники І. П. Козярін, В. Р. Кучма, В. Ф. Лапшин, В. Б. Педан, В. Б. Спиричев зазначали, що достатній рівень та якість харчування у дитинстві $є$ одним з найголовніших факторів, що формують потенціал здоров'я, тривалість, якість життя й працездатність людини упродовж всього життя. Увага низки науковців зосереджена на дослідженні харчового статусу дитячого населення України з метою його корекції та актуалізації, у тому числі цим питанням було присвячено роботи В. І. Берзінь, М. П. Гуліч, В. П. Кульчицької, Н. С. Польки, А. М. Сердюк тощо. Здебільшого наукові напрацювання стосуються медичних та педагогічних аспектів харчування дітей, однак досі залишаються мало дослідженими питання ефективності державного регулювання та маркетингового впливу на безпекові аспекти харчування дітей шкільного віку.

Мета статті: визначити систему індикаторів рівня управління безпеки харчування дітей шкільного віку для оцінювання результативності управління та визначити потенціал підвищення рівня безпеки харчування дітей.

Результати дослідження. Загальне розуміння поняття ефективності управління полягає у якісному виконанні основних функцій, що проявляється у досягненні бажаної мети за результатами здійснення контролю. Система управління безпекою харчування дітей націлена на підвищення рівня безпеки харчування дітей. Розроблений алгоритм моніторингу ефективності управління передбачає циклічність управління на основі впровадження маркетингового механізму управління безпекою харчування дітей шкільного віку (рис. 1).

Зазначені етапі передбачають послідовне виконання завдань, у тому числі оцінки функціювання маркетингового механізму має бути здійснена на основі аналізу динаміки індикаторів, відсутність яких унеможливлює корегування існуючих програм. 3 метою формування науково-методичних підходів оцінювання результативності управління безпекою харчування дітей шкільного віку, вибору критеріїв, підходів до їх оцінки тощо, здійснено контекстний аналіз документів і публікацій, в яких висвітлено питання оцінки ефективності управління у продовольчій сфері. Зокрема, продовольча безпека країни полягає у здатності країни забезпечити населенню доступ до якісних і корисних продуктів харчування. В Україні рівень продовольчої безпеки оцінюють на основі ключових параметрів, зазначених Постановою Кабінету Міністрів України від 05.12.2007 р., а саме:

- добова енергетична цінність раціону харчування людини;

- забезпечення раціону людини основними видами продуктів;

- достатність запасів зерна у державних ресурсах;

- економічна доступність продуктів харчування;

- диференціація вартості харчування за соціальними групами;

- ємність внутрішнього ринку окремих продуктів;

- продовольча незалежність за окремими продуктами [1]. 


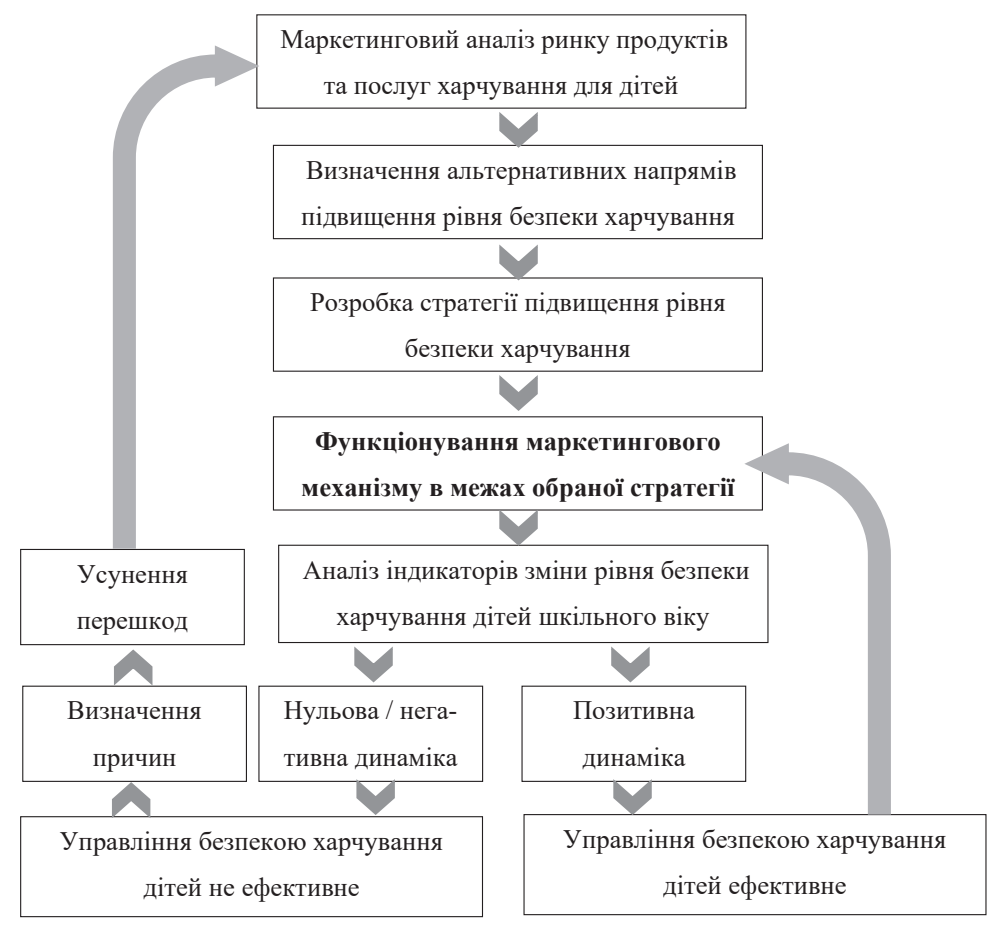

Рис. 1. Алгоритм оцінки ефективності управління безпекою харчування дітей шкільного віку

Джерело: розробка автора.

Римська декларація про всесвітню продовольчу безпеку зазначає обов'язок «кожної країни забезпечити право людини на повноцінне харчування» та окреслює такі компоненти продовольчої безпеки, як фізичну та економічну доступність, продовольчу незалежність, надійність відносно сезонних та погодних коливань та сталий розвиток виробництва $[2$, с. 140]. 3 огляду на зазначені компоненти сформульовано параметри оцінки безпеки харчування дітей (табл. 1).

3 метою оцінки здатності та потенціалу держави забезпечити оптимальний рівень продовольчої безпеки застосовують індекс продовольчої безпеки. У 2010 р. було започатковано формування загального рейтингу Глобального індексу продовольчої безпеки (Global Food Security Index) у 109 країнах світу, який враховував такі показники: якість, безпека, фізична та фінансова доступність продуктів харчування. 3 2014 р. методика визначення Індексу стала враховувати вплив додаткових чинників (ожиріння і продовольчі втрати), які характеризують доступність безпечного, поживного та фінансово доступного продовольства [3]. Вже у 2017 р. введено додатковий чинник визначення GFSI - показник природніх ресурсів та стійкості. 32017 р. оприлюднюють два варіанти Індексу: середній рейтинг продовольчої безпеки на основі трьох основних показників та скорегований рейтинг з урахуванням впливу природніх факторів.

\section{Параметри безпеки харчування дітей, основані на критеріях Римської декларації} про всесвітню продовольчу безпеку

\begin{tabular}{|l|l|}
\hline $\begin{array}{c}\text { Критерії Римської декларації про } \\
\text { всесвітню продовольчу безпеку }\end{array}$ & \multicolumn{1}{|c|}{ Параметри безпеки харчування дітей } \\
\hline 1. Фізична та економічна доступність & $\begin{array}{l}\text { Доступність для дітей необхідної кількості продуктів харчування необхідної яко- } \\
\text { сті. Забезпечення батьків (або осіб, які ї замінюють) ресурсами, необхідними для } \\
\text { забезпечення повноцінного харчування дітей }\end{array}$ \\
\hline 2. Продовольча незалежність & $\begin{array}{l}\text { Забезпечення харчування дітей силами виробників продовольства на внутрішньо- } \\
\text { му ринку }\end{array}$ \\
\hline $\begin{array}{l}\text { 3. Надійність відносно сезонних та } \\
\text { погодних коливань }\end{array}$ & $\begin{array}{l}\text { Врахування впливу макрооточення на систему управління безпекою харчування } \\
\text { дітей, забезпечення гарантованого повноцінного харчування дітей на постійній } \\
\text { основі та розробка адаптивних програм, враховуючи мінливість зовнішнього се- } \\
\text { редовища ринку продуктів харчування для дітей }\end{array}$ \\
\hline 4. Сталий розвиток виробництва & $\begin{array}{l}\text { Підвищення якості харчування дітей за рахунок створення належних умов для ін- } \\
\text { новаційного розвитку виробництва продуктами }\end{array}$ \\
\hline
\end{tabular}

Джерело: розроблено автором 
За даними скорегованого рейтингу у 2019 р. перші три позиція посіли Ірландія, Австрія, Франція, що зумовлено наявністю в цих державах сприятливих погодних умов та продуктів харчування, які $є$ якісними, безпечними, фінансово та фізично доступними. У цих країнах дотримуються високих стандартів виробництва продукції, що дозволяе забезпечувати високий рівень продовольчої безпеки, виробники продуктів харчування мають доступ до дешевих кредитів завдяки державній підтримці, що дозволяє їм забезпечувати потреби внутрішнього ринку у якісних продуктах та експортувати частину виготовленої продукції. Населення наведених країн має високий рівень життя, що обумовлює наявність можливостей забезпечення родин якісними та різноманітними продуктами харчування [3].

Україна у 2019 р. покращила загальний показник GFSI порівняно з попереднім періодом та посіла 76 позицію у рейтингу. Сильними сторонами України є безпека харчових продуктів, низька частка населення за глобальною межею бідності, мінімальні зміни середніх витрат на харчування, низький рівень втрат продовольства. Позитивно впливають на безпеку харчування фінансування програм безпеки харчових продуктів в Україні, наявність відповідних приміщень для зберігання врожаю, здатність безпечно зберігати продукти, залізнична інфраструктура, дієтична різноманітність, наявність поживних мікроелементів в продуктах харчування та відсоток населення, що має доступ до питної води. Основними викликами для країни $є$ корупція, недостатнє державне фінансування наукових досліджень в АПК, відсутність харчових стандартів [3].

Індикатори безпеки харчування дітей можливо розглядати через чотири параметри продовольчої безпеки держави, які зазначені Міжнародною організацією FAO (Food and Agriculture Organization) (табл. 2).

Вважати рівень продовольчої безпеки достатнім можливо за умов виконання усіх чотирьох зазначених параметрів. Результати наукових досліджень доводять, що харчування дітей шкільного віку має бути раціональним (розумним), що передбачає фізіологічне повноцінне харчування з урахуванням особливостей дітей (особливості обміну речовин, стать, вік, характер активності тощо), яке забезпечує постійний стан внутрішнього середовища організму, підтримує його життєві прояви (ріст, розвиток, діяльність різних органів і систем), сприяє зміцненню здоров'я, підвищенню опору організму людини інфекціям. Розумне харчування з урахуванням умов життя, праці, побуту забезпечує сталість внутрішнього середовища організму людини, діяльність різних органів і систем, гармонійний розвиток, високу працездатність [5].

Харчування у дитячому віці закладає фундамент для здоров'я людини на тривалий час. Перше масштабне дослідження, присвячене виявленню зв'язку харчування людей та проблеми поширеності серцево-судинних захворювань, ожиріння й діабету, був проект «Північна Карелія». Цей проект був реалізованим у Фінляндії з 1973 р. За 35 років смертність від серцево-судинних захворювань серед населення Північної Карелії знизилась на 85 \%. Результати цього дослідження було покладено в основу загальноєвропейської «Стратегії з охорони здоров’я - 2020» [6, с. 123].

Таблиия 2

Параметри безпеки харчування дітей, основані на критеріях FAO

\begin{tabular}{|c|c|}
\hline Параметри безпеки харчування FAO & Параметри безпеки хар \\
\hline $\begin{array}{l}\text { 1. Кількісна та якісна достатність забезпечення їжею } \\
\text { населення за рахунок внутрішнього виробництва або ім- } \\
\text { порту (включаючи продовольчу допомогу) }\end{array}$ & $\begin{array}{l}\text { Доступність для дітей необхідної кількості продуктів харчуван- } \\
\text { ня необхідної якості }\end{array}$ \\
\hline $\begin{array}{l}\text { 2. Наявність у населення ресурсів, необхідних для придбан- } \\
\text { ня продуктів, які забезпечують повноцінне харчування }\end{array}$ & 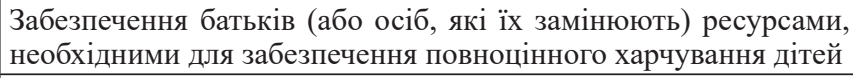 \\
\hline $\begin{array}{l}\text { 3. Процес належного вживання продуктів харчування, до- } \\
\text { ступ до чистої води, підтримка належного рівня санітарії } \\
\text { та охорони здоров’я відповідно до фізіологічних потреб }\end{array}$ & $\begin{array}{l}\text { Забезпечення належних умов харчування, у тому числі за ра- } \\
\text { хунок організації водопостачання, належного рівня санітарії, } \\
\text { врахування індивідуальних потреб та особливостей, виходячи } \\
\text { із стану здоров'я дитини, вікових, статевих, географічних та ін- } \\
\text { ших особливостей }\end{array}$ \\
\hline $\begin{array}{l}\text { 4. Стабільність забезпечення продуктами харчування на } \\
\text { постійній основі }\end{array}$ & $\begin{array}{l}\text { Врахування впливу макрооточення на систему управління без- } \\
\text { пекою харчування дітей, забезпечення гарантованого повноцін- } \\
\text { ного харчування дітей на постійній основі }\end{array}$ \\
\hline
\end{tabular}

Джерело: розроблено автором на основі [4]

Безпечне харчування дітей шкільного віку має забезпечувати фізіологічні потреби дитини, а саме:

- компенсацію витрат енергії;

- дотримання режиму та регулярності споживання їжі;

- забезпечення організму необхідними речовинами з урахуванням статевих, вікових, індивідуальних особливостей організму;

- забезпечення збалансованості раціону харчування для фізичного та інтелектуального розвитку дитини; 
- врахування сезонних особливостей у режимі харчування;

- компенсацію регіонального дефіциту мікроелементів у раціоні [7, с. 19].

У ході поглибленого вивчення стану здоров'я населення встановлено, що хронічні захворювання органів травлення частіше фіксуються при профілактичних оглядах серед населення з низьким соціальноекономічним статусом. Так, виразкова хвороба шлунку та 12-типалої кишки реєструвалася серед найменш матеріально забезпеченої групи у 2,4 рази частіше, ніж серед найбільш заможної, а хронічний гастрит, відповідно, у 3,3 рази. Одноманітний набір продуктів харчування в добовому раціоні сімей, дефіцит свіжих овочів та фруктів призводить до дефіциту вітамінів. У зимовий період тільки 9 \% родин регулярно, 4-5 разів на тиждень, включають до раціону салати зі свіжих овочів, ще рідше вживають у їжу свіжі фрукти. Фактично має місце переважно вуглеводна модель харчування при дефіциті білків тваринного походження. Неповноцінне харчування є також вагомим фактором ризику розвитку захворювань органів травлення. 31990 р. поширеність хвороб органів травлення серед дорослого населення України зросла на 55 \%. Найбільш високими темпами зростала поширеність захворювань підшлункової залози (у 4 рази) та жовчнокам'яної хвороби (у 2,5 рази) [8, с. 8].

Сучасні соціально-економічні умови життя населення України змінюються під впливом значної низки внутрішніх чинників та глобальних тенденцій. Життя сучасних дітей шкільного віку супроводжується зміною умов навчання, запровадженням нових форм та програм. Однак, фізична та фінансова доступність продовольства для забезпечення базових потреб населення у раціональному харчуванні, рівень якості продуктів та забезпеченість продовольчої галузі ресурсами $є$ факторами, що впливають на рівень продовольчої безпеки держави та виступають індикаторами її соціальної стабільності [2, с. 140].

У проекті Закону України «Про продовольчу безпеку України» зазначено основні принципи формування продовольчої безпеки населення, а саме: фізична та економічна доступність якісних та безпечних харчових продуктів для всіх категорій населення в кількості, що необхідна для активного і здорового життя. В цьому ж проекті Закону акцентовано увагу на тому, що під економічною доступністю продуктів харчування слід розуміти стабільну можливість придбання усіма соціальними і демографічними групами населення основних харчових продуктів в цінах, обсягах, асортименті та відповідної якості, необхідних для забезпечення раціонального харчування [9]. Можемо зробити висновок, що отримання дітьми необхідних для забезпечення їх раціонального харчування продуктів має бути одним з критеріїв оцінки рівня безпеки харчування дітей.

Згідно ст. 1 Закону України «Про державну підтримку сільського господарства в Україні» продовольча безпека визначається як захищеність життєвих інтересів людини, яка виражається у гарантуванні державою безперешкодного економічного доступу людини до продуктів харчування з метою підтримання їі звичайної життєвої діяльності [10]. У ст. 1 Закону України «Про основи національної безпеки» продовольча безпека визначається як стан економіки держави, при якому забезпечується продовольча незалежність країни і гарантується стійка та надійна фізична і економічна доступність для всього населення основних видів харчових продуктів, які відповідають встановленим законом вимогам щодо якості та безпечності в кількості, необхідній для активного та здорового життя [10]. Такий підхід до визначення поняття «продовольча безпека» свідчить про те, що безпека харчування здебільшого розглядається як економічне явище, а не тільки медичний аспект.

Н. П. Чорна, досліджуючи ризики продовольчої безпеки, акцентувала увагу на тому, що диференційованість підходів до оцінки рівня продовольчої безпеки полягає у різниці пріоритетів для конкретних регіонів низки складових забезпечення продовольчої безпеки, серед яких фізична і соціальна доступність продовольчих товарів, повноцінне та різноманітне харчування, висока якість і безпечність для здоров'я продуктів харчування [11, с. 116].

Велике значення на модель споживчої поведінки дітей на ринку продуктів та послуг харчування мають зовнішні чинники, у тому числі соціальне оточення, яке сприяє формуванню тих чи інших стереотипів харчової поведінки дітей. Американські вчені довели залежність виникнення таких сучасних проблем із здоров'ям дітей, як ожиріння, від умов проживання у неблагополучних районах, рівня освіченості батьків та психологічної обстановки в сім’ї $[12 ; 13 ; 14]$. Результати значної кількості наукових досліджень доводять, що проживання підлітків в умовах неблагополучних родин збільшує їх шанс на надмірну вагу та ожиріння. Особливий вплив на формування здоров’я дітей спричинює рівень освіти батьків, особливо матерів, адже освіта надає різноманітні переваги, які допомагають батькам сприяти навчанню.

За результатами аналізу та узагальнення існуючих підходів до визначення рівня безпеки харчування визначено ключові індикатори рівня безпеки харчування дітей (рис. 2). 


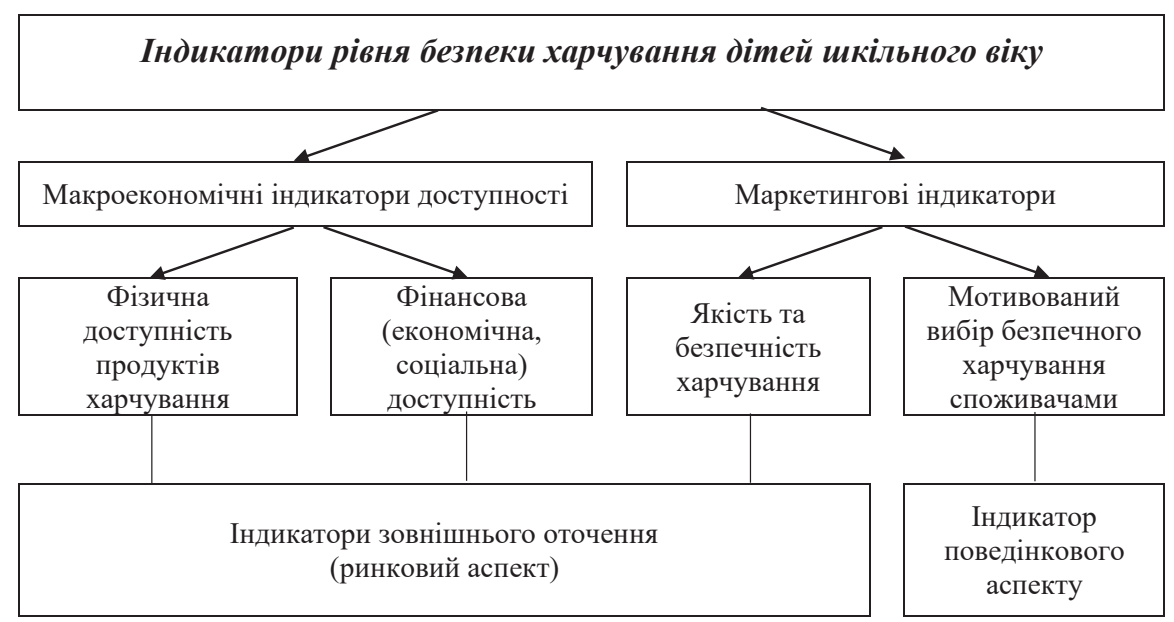

Рис. 2. Індикатори рівня безпеки харчування дітей шкільного віку

Джерело: розробка автора.

Доцільно розрізняти макроекономічні індикатори фізичної та фінансової доступності продуктів харчування та маркетингові (ринкові) індикатори, що передбачають оцінку показників відповідності якості та безпечності продуктів харчування та характер мотивованого вибору продуктів харчування дітьми. На модель споживчої поведінки дітей шкільного віку здійснюють вплив зовнішні чинники, однак мотивація при прийнятті рішення про купівлю обумовлює поведінковий аспект безпеки харчування [15, с. 30]. Сформовано систему часткових показників, які дають змогу оцінити окремі індикатори (табл. 3).

Система показників рівня безпеки харчування дітей

Таблиия 3

\begin{tabular}{|c|c|c|c|}
\hline \multicolumn{3}{|c|}{ Індикатори } & Показники \\
\hline \multirow{2}{*}{ 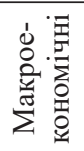 } & \multirow{2}{*}{$\begin{array}{c}\text { Доступність } \\
\text { продуктів } \\
\text { харчування }\end{array}$} & $\begin{array}{c}\text { Фізична } \\
\text { доступність }\end{array}$ & Наявність необхідних продуктів харчування на ринку \\
\hline & & $\begin{array}{c}\text { Фінансова } \\
\text { доступність }\end{array}$ & $\begin{array}{c}\text { Економічна здатність домогосподарств забезпечити повноцінне харчування } \\
\text { Наявність соціального забезпечення держави }\end{array}$ \\
\hline \multirow{2}{*}{ 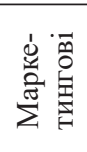 } & \multicolumn{2}{|c|}{ Якість та безпечність харчування } & $\begin{array}{l}\text { Показники безпеки продуктів харчування та їх відповідність стандартам } \\
\text { Показники якості послуг харчування для організованих дитячих колективів }\end{array}$ \\
\hline & \multicolumn{2}{|c|}{$\begin{array}{l}\text { Мотивований вибір безпечного } \\
\text { харчування }\end{array}$} & $\begin{array}{c}\text { Сформована безпеково-орієнтована модель споживчої соціалізації дітей на } \\
\text { ринку продуктів та послуг харчування }\end{array}$ \\
\hline
\end{tabular}

Джерело: розроблено автором

Доречність поведінкового аспекту доведена у роботах вітчизняних науковців. Так, Г. А. Анохіна, В. В. Харченко, Н. В. Харченко у своїх наукових роботах доводять необхідність українцям переглянути своє ставлення до харчування та способу життя з метою покращення якості життя, збереження здоров'я, профілактики хронічних неінфекційних захворювань тощо. Науковці стверджують, що основою традиційного харчування населення України мають бути натуральні традиційні продукти, яким слід віддавати перевагу при виборі харчування. Існує необхідність раціоналізації споживчої поведінки українців: дотримання помірності в їжі, обмежене вживання рафінованих продуктів, особливо солодощів та жирів низької якості [7, с. 19].

Оцінку індикаторів управління безпекою харчування дітей доцільно здійснювати на основі отриманих в ході досліджень даних, застосовуючи відповідні методи отримання інформації (табл. 4).

Аналіз індикаторів фізичної та фінансової доступності продуктів харчування, їх якості та безпечності, а також індикатора поведінкового аспекту дітей шкільного віку на ринку продуктів та послуг харчування дозволять оцінити ефективність маркетингового механізму управління безпекою харчування дітей.

В разі виявлення позитивної динаміки можливо стверджувати про ефективність управління та необхідність дотримуватись обраної стратегії. Якщо ж наявна негативна динаміка, це свідчитиме про необхідність перегляду обраної стратегії на основі отриманих попередніх результатів та оцінки поточного стану зовнішнього середовища ринку. 
Методи отримання інформації про індикатори управління безпекою харчування дітей

\begin{tabular}{|c|c|c|c|}
\hline \multicolumn{2}{|c|}{ Індикатори } & Метод отримання даних & Джерела інформації \\
\hline \multirow{2}{*}{ 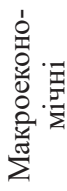 } & \multirow{2}{*}{ 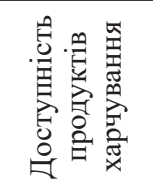 } & $\begin{array}{c}\text { Проведення кабінетного дослідження } \\
\text { Аналіз вторинної інформації }\end{array}$ & $\begin{array}{c}\text { Офіційні статистичні дані, результати наукових досліджень, } \\
\text { аналітичні звіти проведеного моніторингу }\end{array}$ \\
\hline & & $\begin{array}{c}\text { Проведення польового дослідження } \\
\text { Аналіз первинної інформації }\end{array}$ & $\begin{array}{c}\text { Оцінка стану макромаркетингового середовища } \\
\text { Опитування експертів }\end{array}$ \\
\hline \multirow{4}{*}{ 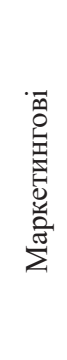 } & \multirow{2}{*}{ 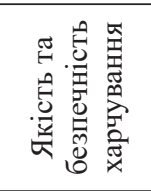 } & $\begin{array}{c}\text { Проведення кабінетного дослідження } \\
\text { Аналіз вторинної інформації }\end{array}$ & $\begin{array}{c}\text { Офіційні статистичні дані, результати наукових досліджень, } \\
\text { аналітичні звіти проведеного моніторингу } \\
\text { Оцінка стану мікромаркетингового оточення }\end{array}$ \\
\hline & & $\begin{array}{c}\text { Проведення польового дослідження } \\
\text { Аналіз первинної інформації }\end{array}$ & $\begin{array}{c}\text { Опитування дітей та їх батьків щодо задоволеності якістю } \\
\text { продуктів та послуг харчування }\end{array}$ \\
\hline & \multirow{2}{*}{ 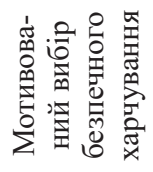 } & $\begin{array}{l}\text { Проведення кабінетного дослідження } \\
\text { Аналіз вторинної інформації }\end{array}$ & $\begin{array}{c}\text { Результати наукових досліджень, аналітичні звіти проведеного } \\
\text { моніторингу }\end{array}$ \\
\hline & & $\begin{array}{c}\text { Проведення польового дослідження } \\
\text { Аналіз первинної інформації }\end{array}$ & $\begin{array}{c}\text { Опитування дітей та їх батьків з метою визначення моделі } \\
\text { споживчої поведінки дітей шкільного віку }\end{array}$ \\
\hline
\end{tabular}

Джерело: розроблено автором

Висновки. За результатами проведеного дослідження визначено алгоритм контролю ефективності управління безпекою харчування дітей шкільного віку, який передбачає виконання послідовних етапів, що являють собою цикл управління. 3 метою прийняття рішень щодо доцільності реалізувати прийняту стратегію або корегувати обраний напрям запропоновано використовувати систему індикаторів управління безпекою харчування дітей шкільного віку. Конкретизовані показники розробленої системи індикаторів, зазначені методи отримання інформації. Подальші дослідження передбачають аналіз стану ринку продуктів та послуг харчування дітей шкільного віку, а також визначення моделі споживчої поведінки дітей для розробки напрямів впровадження маркетингового механізму управління безпекою їх харчування.

\section{Література:}

1. Постанова Кабінету Міністрів України «Про деякі питання продовольчої безпеки» від 5 грудня 2007 року. URL: https://zakon.rada.gov.ua/laws/show/1379-2007-\%D0\%BF (дата звернення: 15.11.2020).

Cabinet of Ministers of Ukraine (2007), " Resolution of the Cabinet of Ministers of Ukraine "On some issues of food security"', available at: https://zakon.rada.gov.ua/laws/show/1379-2007-\%D0\%BF (2020, november, 15).

2. Коноваленко А. С. Параметри оцінки безпеки харчування дітей. Менеджмент та маркетинг у складi сучасної економіки, науки, освіти, практики : Щорічний збірник наукових робіт. Матеріали VII міжнародної науково-практичної дистаниійної конферениії (м. Харків, 21 березня 2019 р.). 2019. С. 139-142.

Konovalenko, A.S. (2019). Parametry otsinky bezpeky kharchuvannia ditei. [Parameters for assessing the safety of children's nutrition]. Menedzhment ta marketynh u skladi suchasnoi ekonomiky, nauky, osvity, praktyky: Materialy VII mizhnarodnoi naukovo-praktychnoi dystantsijnoi konferentsii. [Management and marketing as a part of modern economy, science, education, practice: materials of the $7^{\text {th }}$ international scientific-practical distance conference]. (Kharkiv, march, 21), 139-142. [In Ukrainian].

3. Global Innovation Index 2019: Creating Healthy Lives-The Future of Medical Innovation. The Global Innovation Index. < https://www.globalinnovationindex.org/userfiles/file/reportpdf/gii-full-report-2019.pdf > (2019, September, 15) [in English].

4. FAO Policy Brief - Food Security. < ftp.fao.org/es/ESA/policybriefs/pb_02.pdf > (2019, September, 15) [in English].

5. Рудавка С. І. Економічні проблеми раціонального харчування та його роль у покращенні здоров'я населення України. Вісн. Вінницького нац. мед. ун-ту. Т. 17. 2013. № 2. С. 475-481.

Rudavka, S. I. (2013). Ekonomichni problemy ratsionalnoho kharchuvannia ta yoho rol u pokrashchenni zdorovia naselennia Ukrainy [Economic problems of rational nutrition and its role in improving the health of the population of Ukraine]. Visnyk Vinnyts'koho natsional'noho medychnoho universytetu [Visn. Vinnytsia National Medical University], 2, 17, 475-481. [in Ukrainian]

6. Горбась I. М. Профілактика хронічних неінфекційних захворювань - реальний шлях поліпшення демографічної ситуації в Україні. Украӥнський кардіологічний журнал. 2009. № 3. С. 6-11.

Horbas, I.M. (2009). Profilaktyka khronichnykh neinfektsiinykh zakhvoriuvan - realnyi shliakh polipshennia demohrafichnoi sytuatsii v Ukraini. [Prevention of chronic non-communicable diseases is a real way to improve the demographic situation in Ukraine]. Ukrains'kyj kardiolohichnyj zhurnal [Ukrainian Journal of Cardiology], 3, 6-11. [in Ukrainian]

7. Харченко Н. В., Анохіна Г. А., Харченко В. В. Соціально-еволюційне та патогенетичне обгрунтування національної піраміди харчування. Здоров'я Украӥни. 2014. № 4. С.18-20. 
Kharchenko, N.V., Anokhina, G.A., Kharchenko, V.V. (2014). Socio-evolutionary and pathogenetic substantiation of the national food pyramid. Zdorov'ia Ukrainy [Health of Ukraine], no. 4, pp. 18-20 (In Ukrainian).

8. Москаленко В. Ф., Пономаренко В. М., Грузєва Т. С. Система скорочення нерівності в охороні здоров’я населення та її прогнозна ефективність. Вісник соиіальної гігієни і організації охорони здоров’я. 2004 . № 2. C. 5-10.

Moskalenko, V.F., Ponomarenko, V.M., Gruzeva, T.S. (2004). Systema skorochennia nerivnosti v okhoroni zdorovia naselennia ta yii prohnozna efektyvnist [The system of reducing inequalities in public health and its projected effectiveness]. Visnyk sotsial'noi hihiieny i orhanizatsii okhorony zdorov'ia [Bulletin of social hygiene and health care organization], 2, 5-10. [In Ukrainian].

9. Проєкт Закону про продовольчу безпеку України (Верховна Рада України). Офіційний сайт Верховної Ради України. URL: http://w1.c1.rada.gov.ua/pls/zweb2/webproc34?id=\&pf3511=40276\&pf35401=191014 (дата звернення: 15.09.2020).

Proekt Zakonu pro prodovolchiu bezpeku (Verkhovna Rada Ukrajiny). [The Project of the Law about food security], $<$ http://w1.c1.rada.gov.ua/pls/zweb2/webproc34?id=\&pf3511=40276\&pf35401=191014 > (2020, September, 15) [in Ukrainian].

10. Закон про державну підтримку сільського господарства в Україні 2004 (Верховна Рада України). URL: https://zakon.rada.gov.ua/laws/show/1877-15 (дата звернення: 15.09.2020).

Zakon pro derzhavnu pidtrimku Ukrajiny 2004 (Verkhovna Rada Ukrajiny). [Law on state support of agriculture in Ukraine (Verkhovna Rada of Ukraine)]. < https://zakon.rada.gov.ua/laws/show/1877-15 > (2020, September, 15) [in Ukrainian].

11. Чорна Н. П. Інноваційний розвиток сфери виробництва продуктів харчування та ризики продовольчої безпеки : монографія. Львів : Ліга-Прес, 2012.

Chorna, N. P. (2012). Innovatsijnyj rozvytok sfery vyrobnytstva produktiv kharchuvannia ta ryzyky prodovol'choi bezpeky: monohrafiia [Innovative development of food production and food security risks: a monograph]. Lviv, LigaPress.

12. Alvarado, S. E. (2016). Neighborhood disadvantage and obesity across childhood and adolescence: Evidence from the NLSY children and young adults cohort (1986-2010). Social Science Research. 57, 80-98.

Alvarado, S. E. (2016). Neighborhood disadvantage and obesity across childhood and adolescence: Evidence from the NLSY children and young adults cohort (1986-2010). Social Science Research. 57, 80-98. [In English]

13. Berge, Jerica M. (2016). He Said, She Said: Examining Parental Concordance on Home Environment Factors and Adolescent Health Behaviors and Weight Status / [et al.]. Journal of the Academy of Nutrition And Dietetics. 116, vol. $1,46-60$.

Berge, Jerica M. (2016). He Said, She Said: Examining Parental Concordance on Home Environment Factors and Adolescent Health Behaviors and Weight Status / [et al.]. Journal of the Academy of Nutrition And Dietetics. 116, vol. 1, 46-60. [In English]

14. Prickett, K. C., Augustine, J. M. (2016). Maternal Education and Investments in Children's Health. Journal of Marriage And Family. 78, vol. 1, 7-25.

Prickett, K. C., Augustine, J. M. (2016). Maternal Education and Investments in Children's Health. Journal of Marriage And Family. 78, vol. 1, 7-25. [In English]

15. Коноваленко А. Управління безпекою харчування дітей. Food Industry Economics. 2020. № 12 (1). URL: https://doi.org/10.15673/fie.v12i1.1666 (дата звернення: 15.11.2020).

Konovalenko, A. (2020). Upravlinnia bezpekoiu kharchuvannia ditei [Children nutrition safety management]. Food Industry Economics, 12 (1). $<$ https://doi.org/10.15673/fie.v12i1.1666 > (2020, november 15). [in Ukrainian] 